\title{
Opening Pandora's Box: A Culturally-oriented Look at the Covert Content of Passages 1
}

\author{
Yazdan Choubsaz \\ Mohsen Jannejad \\ Saleh Arizavi \\ English Language Department \\ Shahid Chamran University of Ahvaz, Iran \\ Email:yazdanchoobsaz@yahoo.com,m_jannejad@yahoo.com
}

\begin{abstract}
This study investigates the cultural content and covert syllabus of one well-known widely printed English Language Teaching (ELT) course book: Passages 1. In order to analyse the content, two coding systems the Five Dimensions of Culture and the Categories of Culture by Chao (2011) were used. The findings indicate that Passages 1 has encouraged various aspects of culture with an emphasis on the presentation of products, persons and viewpoints of the West. The partiality for the Target Culture (countries with English as the native language) is clear throughout the course book in terms of the selection of reading texts, listening tracks, and the images. Findings indicate that there is a minimal focus on the introduction of local and the Middle Eastern cultures. The theme of 'universality across cultures', as a specific classification in this study, is mostly placed in the speaking practices which revolves around sharing personal experiences rather than engaging in intercultural thinking and awareness. Based on the findings, some recommendations are given to ensure some aspects of the target culture are adequately addressed in the writing of ELT course books.
\end{abstract}

Keywords: Covert syllabus, analysis of content, intercultural aspects, cultural content, universality of cultures

\section{INTRODUCTION}

As two important trends, globalization and internationalization have made significant contributions in upholding English a 'necessity' and an 'important' concern from elementary schools to universities in Iran and in other countries in the Middle East. Just like many other Asian countries (Choi \& Lee, 2008), internationally printed English course books are used by many teachers in Iran. Course books of reputable publications like Cambridge University Press, Oxford University Press and Pearson Longman are widely available in the Middle East market to fulfill the immediate needs of university and learners of higher institutions as it is believed that a 'growing need' for English is felt in these countries (British Council's Report, 2006).

Beyond that need, the significance of teaching culture in classrooms is highlighted in the words of many language teachers and scholars (Chang, 2004; Damen, 1987; Kramsch, 1991; 1998; Lange \& Paige, 2003), and as the vital sources of linguistic 
and cultural knowledge, course books pave the way for a systematic language learning in English-as-a-Foreign Language (EFL) classes. Yet, in the past few years, most of the studies done on the cultural content of English course books in Iran, as a Middle Eastern EFL context, have concentrated on the categories of course books that are approved socially and printed locally in elementary or high school levels (Ajideh \& Panahi, 2016; Aliakbari, 2005) or nation-wide institutes (Rashidi \& Najafi, 2010).

The fact is, although college English instructors prefer to utilize the mentioned course books, a small number of studies have been carried out in academic contexts to investigate cultural content in prevalent well-known publications. Such 'imported' course books that are mostly authored by ELT practitioners and English speaking writers are regarded linguistically and culturally rich and therefore 'better' than the locally printed ones. Nevertheless, there are studies (Apple \& Christian-Smith, 1991; Jackson, 1990; Margolis, 2001) that reveal the concepts or principles covert within texts, named covert syllabus, that are indirectly delivered while the content of course books is passed on to learners. As a result, learners' attitudes and social tolerance might be unintentionally influenced by a set of routines and behaviors that have been reflected in these course books. That is why a precise investigation in EFL contexts is needed to come up with an analysis of the course books the English native speakers edit/write. After all, figuring out the possible covert syllabus that may/may not affect widelyaccepted ELT course books and their cultural content is an important role of teachers; a role that makes the selection of course books a more reflective task on their side.

\section{REVIEW OF THE RELATED LITERATURE}

As a reminder to English teachers worldwide and to draw on the fact that course books printed internationally cannot be impeccable, Alpektin (2002) once argued that the cultural elements of the U.K. or the States (target language cultures) are reflected in such course books; and their content might meddle with the ordinary inclination of EFL learners' cognition of their own definite culture. Additionally, pinpointing their unfair nature, Pennycook (1994) claimed that internationally printed books are the western manifestation of concepts like language, communication, and learning. Cortazzi and Jin (1999) also highlighted the ideological elements that EFL course books represent to both teachers and learners. They drew on the drawbacks of heavy reliance on such course books as the major source of teaching.

McKay (2002) gave a new vision to the issue by stressing the significance of cultivating intercultural understanding while presenting a course of EFL. He continued by putting forward the idea of an integration of the three kinds of cultures, i.e. the international, the source and the target culture, all in EFL course books, to fulfill the necessities of various language learners. Canagarajah (2003) is the other scholar who underscores the realization of the effects of internationally printed course books on the local syllabus of EFL countries. He believes in spite of considering these course books as culturally inappropriate, many teachers still stick to these pre-made syllabi only because of few practical motives like lack of facilities or time. Zacharias's (2005) study on Indonesian English teachers' opinions about the content of course books is another challenging example. In this case, both the language and cultural dimensions were too out-of-the-way to be figured out by the language learners. Or in another case, 
considering the Middle Eastern context, Ahmadi (2013) took a "constructive pragmatic approach in using culture successfully in Iranian and non-Iranian ELT course books" (p. 23); a study through which she rejected a full acceptance of internationally printed course books and emphasized the provision of rudimentary linguistic, communicative and intercultural skills for the students to visualize their own society and represent their own culture in the target culture. As it can be observed, investigating the cultural content of these course books and also delving into their potential effects on EFL learners have been among the main purposes of conducting these studies in the literature.

\section{RESEARCH OBJECTIVES AND QUESTIONS}

In the words of various researchers (Giroux, 1988; Huang, 1990 \& 1993; Huang \& Lu, 2006; Jackson, 1990; Myles \& Simpson, 2001 as cited in Chao, 2011), covert syllabus is referred to the results or up-shots that are produced unintentionally while dealing with school setting experiences e.g. teaching techniques and also course books. To examine this covert syllabus in the cultural content of an ELT internationally printed course book Passages 1, by Cambridge University Press (2015), and to explore the probable views, morals, ideals or principles conveys via the content of this course book (for instance reading or audio materials), this study draws on the method of content investigation with cultural dimensions in focus. The following research questions comprise the main framework of the current study:

1. How is the presentation of cultural content and intercultural concerns in Passages 1?

2. What is the covert syllabus of the cultural content and intercultural concerns conveyed via Passages 1 ?

\section{The Course Book under Scrutiny}

The student book of Passages 1 by Cambridge University Press was the internationally printed ELT course book that was considered for precise evaluation. During summer 2017 and in a well-known private language institute in the west of Iran, this specific course book was assigned to a group of high-intermediate learners as their general English course material. Scrutinizing each chapter's topic, examining main texts of the book via content investigation, and delving into its covert syllabus exposed to learners were among the steps taken to realize whether the cultural dimensions of this widelyaccepted course book can fulfill the ongoing necessities of EFL learners.

\section{Content Investigation}

To recognize adequate classifications of the cultural content through main texts of the course book, Content Investigation (CA) was utilized in the current study. Referring to Cohen, Manion and Morrison (2000) and Neuman (1997), this content in focus manifests itself as lexis, images, opinions or any type of message that can be talked about. The text is reflected through pictorials, printed or oral forms and would come handy as a means of communication while dealing with textbooks, movies or even documents. Based on Cohen, Manion and Morrison (2000) and Neuman (1997), and since overt and clear rules are pursued through the process of categorizing and ordering 
data, CA is often times regarded as an independent and consistent technique in both historical and academic research.

\section{The Two Coding Systems}

As two coding systems that codify data, the Five Dimensions of Culture and the Main Categories of Culture by Chao (2011) were utilized. Moran's (2001) viewpoint formed the basis of the first coding system based on which a range of cultural aspects in each chapter of the book alongside the relevant themes of the book were employed. The development of the Main Categories of Culture was based on proposals from experts endorsing the progress of intercultural communicative competence (Alpektin, 2002; Byram, 1997; Cortazzi \& Jin, 1999; Mckay, 2002 as cited in Chao, 2011). It was mostly employed to get to know the sort of culture and intercultural concerns. What follows is the elaboration of the two coding systems.

\section{The Five Dimensions of Culture}

When it comes to English learning and teaching, one can hardly deny the role of culture. The intricacy and multifaceted aspects of culture alongside its limited meaning have made some scholars in language education argue that learners would hardly realize the variety of attitudes occur in the social setting of the target country. Hence, they emphasize the significance of perceiving culture in a broader sense (Gill \& Cánková, 2003; Hall, 2002; Seelye, 1993; Tomalin \& Stempleski, 1994 as cited in Chao, 2011). There were then some divergent perceptions proposed by experts form the trials carried out to clarify the rudiments or aspects of culture. Two examples are 'big C', 'small c' (Basttista, 1984) and objective versus subjective culture (Bennett, 1993). Besides, various demonstrations in products, activities and viewpoints are also suggested about culture as the same three-sided notion (Fantini, 1997; Lado, 1997; National Standards in Foreign Education Project, 1999; Tomalin \& Stempleski, 1994 as cited in Chao, 2011). Yet, due to lack of harmony between the presence of people and these elements, Moran (2001) finds the three-sided notion of culture immature. Thus, he brings in two more sides to the story, namely persons and communities, and sums up with the five aspects or sides of culture: products, activities, viewpoints, persons and communities. In the end, he elaborates on culture as a changing way of life of a group of people that includes similar activities, is connected to similar products, is found based on similar viewpoints of the world and is set within particular social settings. To draw on the aspects of culture, Moran (2001) believes products are linked to persons who utilize different activities in communities that reflect their viewpoints. Bearing this definition in mind, culture can then be seen as the integration of products, activities, communities, persons and viewpoints. Being comprehensive, these five aspects were applied to scrutinize the cultural dimensions (elements) mirrored in each chapter and its relevant themes of Passages 1. A concise statement of these five aspects of culture can be seen in Table 1. 
Table 1: A Concise Summary of the Five Aspects of Culture (Moran, 2001 as Cited in Chao, 2011)

\begin{tabular}{ll}
\hline Aspects & \multicolumn{1}{c}{ Instances } \\
\hline Products & 1. Artifacts: food, documents, language, money, tools \\
& 2. Places: buildings, cities, houses \\
& $\begin{array}{l}\text { 3. Institutions: family, law, economy, religion, education, } \\
\text { politics }\end{array}$ \\
& 4. Art forms: music, clothes, dancing, painting, movie, \\
& Architecture
\end{tabular}

Viewpoints The insights, principles, ideals and attitudes that lie behind the products and lead people's moralities in the practice of culture are depicted here. Although mostly indirect, they can be direct and are formed out of conscious alertness.

Communities $\quad$ Special social settings (e.g. national cultures), situations (e.g. holy rituals) and groups (e.g. various social gatherings) through which cultural activities are done and performed are included here.

Persons $\quad$ People who represent the culture and its groups in specific ways are here. Their individual identity and history of life are effective in the progress of a single cultural person.

\section{The Main Categories of Culture}

As an internationally widely-accepted language, English is used for financial, societal and technical objectives today (Graddol, 2007). With its extensive spread, the aim of learning this language is mostly the communication of people with each other all over the globe (Mckay, 2002). Having this aim for English in mind, one may point to the impractical views that the communicative competence model (Canale \& Swain, 1980) has developed in English language teaching (Alpektin, 2002). Thus, intercultural communication competence (ICC) that was the add-on to communicative competence (Cortazzi \& Jin, 1999; Lázár, 2007), has played an important role while dealing with English teaching and learning as well as interpersonal communication (Alpektin, 2002; Brooks, 2004; Byram, 1997; Byram, Nichols \& Stevens, 2001; Chao, 2009, 2010 as cited in Chao, 2011). The longitudinal studies on intercultural communication in America and Asia led Scollon and Scollon (1995, p. 12) to state that: "real communication is based on sharing as much as probable assumptions we make about what other people mean". The other scholar is Byram (1997) who states that effective communication cannot be established with mere progression of communicative competence, and speakers of various cultural classes may face misunderstandings. Put it another way, expecting EFL learners to adopt cultural routines of native speakers does not seem logical. As an 
alternative, equipping them with both communicative and intercultural competence for having an effective intercultural communication is a better idea (Ahmadi, 2013). Cortazzi and Jin (1999) therefore, suggest three kinds of cultural facts i.e. 1) target culture content, 2) local culture content, and 3) international culture content to be included in EFL course books. If we want learners with a developed intercultural communicative competence, we need to deliver different prospects like using well-established unbiased English course books (Chao, 2010).

According to ideas and recommendations of aforementioned scholars, the Main Categories of Culture was established by Chao (2011) and two of her research assistants and they were used in the current study. Their paradigm was an evaluation guide to delve into the inclination of cultural kinds and intercultural concerns available in the main sections (practices) of Passages 1. In the end, Source/Local Culture (SC), Target Culture (TC), International Culture (IC), Intercultural Interaction (ICI) and Universality across culture (UC) were decided as five classifications of culture (Chao, 2011). A full account of this coding system is presented in Table 2.

Table 2: The Main Categories of Culture (Adopted from Chao, 2011)

\begin{tabular}{ll}
\hline Cultural Classifications & \multicolumn{1}{c}{ Accounts } \\
\hline Source Culture (SC) & $\begin{array}{l}\text { It refers to the Middle East culture (the cultural norms } \\
\text { accepted in the Middle East) }\end{array}$ \\
Target Culture (TC) $\quad \begin{array}{l}\text { It contains English as the native language (The United } \\
\text { States, The United Kingdom, New Zealand, Ireland, } \\
\text { Canada, Australia) }\end{array}$ & $\begin{array}{l}\text { It contains cultures of all countries of the globe (Latin } \\
\text { International Culture } \\
\text { (IC) }\end{array}$ \\
exception of the Middle Eastern and English-speakers' \\
cultures.
\end{tabular}




\section{DATA ANALYSIS}

The student book of Passages 1 and its twelve units (twenty-four parts) were the source of the raw data. The book also included 4 sections as 'communication reviews'. The researcher and his colleague, as the coders, did the content coding of this course book. The Five Dimensions of Culture and the Main Categories of Culture, as the two coding systems, were talked about before the coding job began. However, using these coding systems, the coders worked separately on their own to make the outcome of data analysis more consistent. Most of the interpretations and coding of different sections of the course book were the same in both researchers' opinions, suggesting that they were largely in accord in their judgments. In cases where initial disagreement arose, the researchers discussed the content in question with an experienced colleague to reach an agreement.

\section{Cultural Aspects Analysis}

To figure out the spread of cultural aspects, the major text of each chapter of Passages 1 was examined at this point. For instance, one of the themes in Chapter 1 is about comparing families (p. 8 and p. 9). It was coded under cultural aspect Viewpoints/ insights and attitudes. A well-known musician (Dave Carroll) is talked about in the reading of Chapter 7 (p. 87), thus this section is coded under the cultural aspects Persons and Activities/lives. Additionally, the section Customs and Traditions (p. 98) in Chapter 12, and the Starting Point elaborating on making small talks in parties in Chapter 5 (p. 36) were both coded under the cultural aspect Communities/special social settings. Or talking about cities (Melbourne and Sydney and their rivalry), a reading that is presented in Chapter 3 (p. 25) was coded under Products/ places in the analysis. In Table 3 the coding guide can be seen with an example.

Table 3: An Example of Coding Guide Utilized for Cultural Aspects Analysis (Adopted from Chao, 2011)

\begin{tabular}{lll}
\hline Book Chapter & Topics Covered & Cultural Aspects \\
\hline Unit 3, Reading & Comparison of 2 cities & Products (places in 2 cities) \\
& & Viewpoints (how the people \\
& see their cities)
\end{tabular}

\section{Cultural Categories Analysis}

As a way to codify the cultural classifications (cultural kinds and intercultural concerns) of the Passages 1 , three subdivisions were considered when analyzing the content: 1) major reading comprehensions and listening tracks (skills that are receptive), 2) major oral and writing activities (skills that are productive), and 3) major images (are named pictorials). The coding guide can be observed in the Appendix. 
Due to the possibility of a lack of focus on any specific culture or setting, the content that is mostly linked to linguistic practices was coded under Universality across Culture (UC). These were contents that mainly mirror the happenings in countries with English as the native language (United States, United Kingdom, New Zealand, Ireland, Canada, and Australia), they were coded under Target Culture (TC). A listening track on Family Reunion (Chapter 1, p. 8) was an example. The content in focus was coded as International Culture (IC) if it was linked to cultures of various countries of the globe (i.e. Latin Americans, Europeans, Africans and Asians) with the exception of the Middle East and countries with English as the native language. Intercultural Interaction (ICI) was of help to learners think about similarities or dissimilarities between their home and target (or even international) culture. Yet, few writing activities and listening tracks were instances of ICI during the process of coding this category. Most ICI instances were in oral activities focusing on individual sharing and fundamental thinking, like talking to the class or a partner about your past experiences (Chapter 2, p.11). Lastly, Source Culture (SC) was used to codify the content related to the Middle East culture. However, there hardly was an instance or information about this kind of culture throughout the course book (one or two instances in the whole book).

In the current research, analyzing major images of the content (pictorials) was the least objective task at hand; specifically when it is compared to the analysis and codification of linguistic content. Nonetheless, the coders discussed the issue and decided to consider appearance of the course book characters and products visualized in the images as issues or criteria for codification. Quite a few images pertained to Target Culture (TC), a large number were coded under International Culture (IC) and few were classified both under Universality across Culture (UC) and Intercultural Interaction (ICI).

\section{RESULTS}

\section{Passages 1 and its Cultural Aspects}

By taking a closer look at the spread of cultural dimensions after content analysis, and although communities represent a lower percentage, it can be seen that various dimensions of culture is included in the target course book (Table 4). To be more specific, $67 \%$ of the content of the book is allocated to direct or indirect demonstration of viewpoints of various cultures. Everyday practices e.g. parties, movies, family reunions, transportation, radio and TV shows that are classified under products contained $58 \%$ of the content of the course book. Activities that mainly focused on arts, scenarios and lives of different characters of the book in countries with English as the native language contained $42 \%$ of the content. And finally $58 \%$ allocated to the presentation of Persons who were members of the Target Culture (TC) (e.g. the Watsons and the Patels in Chapter 1, p. 6). 
Table 4: The Cultural Aspects of Passages 1

\section{Cultural Aspects $\quad$ Products Activities Viewpoints Communities Persons}

\begin{tabular}{lrrrrr}
\hline Percentages & $58 \%$ & $42 \%$ & $67 \%$ & $8 \%$ & $58 \%$ \\
& & & & & \\
Accounts per book part & {$[14 / 24]$} & {$[10 / 24]$} & {$[16 / 24]$} & {$[2 / 24]$} & {$[14 / 24]$} \\
\hline
\end{tabular}

\section{Passages 1 and Its Cultural Classifications}

Regarding the spread of five major cultural classifications in this course book, Target Culture (TC) and Universality across Culture (UC) are clearly favored (see Table 5). These two outperformed the other classifications in almost a tangible way, specifically when it came to pictorials, reading comprehensions and oral activities. The cultural content and intercultural concerns of oral practices in Passages 1 were codified under the category Universality of Culture (UC) with the percentage $96 \%$ that is considered high in nature. Except that, it turned out that $46 \%$ of oral practices was coded under the category ICI (Intercultural Interaction). However, such intercultural oral activities mostly dealt with individuals thinking about a special issue rather than critical intercultural thinking and argument. Additionally, the images shown in the course book are very close to English native speakers (TC), Europeans and Latin Americans (IC). Consequently, in most of the cultural classifications, the Source Culture (SC) has become a minority.

Table 5: Cultural Classifications in a Concise List

\begin{tabular}{lccccc}
\hline Content & \multicolumn{5}{c}{ Cultural Classifications } \\
\hline & SC & TC & IC & ICI & UC \\
\cline { 2 - 6 } $\begin{array}{l}\text { Reading } \\
\text { comprehension }\end{array}$ & $4 \%$ & $79 \%$ & $42 \%$ & $42 \%$ & $17 \%$ \\
& {$[1 / 24]$} & {$[19 / 24]$} & {$[10 / 24]$} & {$[10 / 24]$} & {$[4 / 24]$} \\
\hline $\begin{array}{l}\text { Listening } \\
\text { Tracks }\end{array}$ & $4 \%$ & $42 \%$ & $12 \%$ & $25 \%$ & $50 \%$ \\
& {$[1 / 24]$} & {$[10 / 24]$} & {$[3 / 24]$} & {$[6 / 24]$} & {$[12 / 24]$} \\
\hline Oral activities & $4 \%$ & $37 \%$ & $8 \%$ & $46 \%$ & $96 \%$ \\
& {$[1 / 24]$} & {$[9 / 24]$} & {$[2 / 24]$} & {$[11 / 24]$} & {$[23 / 24]$} \\
\hline Writings & $8 \%$ & 0 & $4 \%$ & $4 \%$ & $29 \%$ \\
& {$[2 / 24]$} & & {$[1 / 24]$} & {$[1 / 24]$} & {$[7 / 24]$} \\
\hline Pictorials & $4 \%$ & $100 \%$ & $79 \%$ & $54 \%$ & $8 \%$ \\
& {$[1 / 24]$} & {$[24 / 24]$} & {$[19 / 24]$} & {$[13 / 24]$} & {$[2 / 24]$} \\
\hline
\end{tabular}




\section{DISCUSSION}

\section{The First Research Question}

To answer the first research question, 'how is the presentation of cultural content and intercultural concerns in Passages 1?', considering the overall content, the main section of each chapter of this course book deals with the activities of linguistic knowledge, codified as UC. Bearing in mind that Passages 1 is planned to be utilized in every corner of the world, penetrating high dosages of UC content may come handy in attracting more and more English learners from various cultural origins. Yet, overviewing the findings reveal that Target Culture as a 'cultural classification' and Viewpoints as a 'cultural aspect' affect the choice of content of the course book. It goes without saying that the other 'cultural sorts' like IC and dimensions such as 'persons' and 'products' have played their own roles and been included in different sections of the course book, too. Put it another way, reading comprehensions, listening tracks and pictorials have all helped the authors out in incorporating the attitudes and principles of the Target Language in the content of this course book.

Although not to a significant degree, the oral practices of the course book under investigation have been affected by the target culture aspects. Whenever it came to an indication of the culture of the world, codified as International Culture (IC), the attention was paid to European and Latin American countries. They were mostly shown in reading comprehensions and pictorials of the course book. The other point is, the presence of the Source Culture (the Middle East countries) can hardly be seen all through this course book. And in the end, oral activities, reading comprehensions as well as pictorials were partially reflected in Intercultural Interaction (ICI) classification. However, a deep intercultural reflection and analysis was not pictured and the practices were mostly based on sharing of ideas and linguistic production.

\section{The Second Research Question}

The analysis of the content and its cultural aspects and classifications were carried out to answer the second research question. Through the findings it was figured out that in an indirect or direct way, Passages 1 might deliver some covert beliefs or ideas to its EFL users despite the chances it might create for them pursuing some pedagogical purposes. Here are some examples:

As can be seen in the second part of Chapter 1, in the 'Starting Point' precisely, an English Australian family is the two-income small family, but the Chinese family in the second part of that section is populated and with many family members. From a cultural point of view, this image might show the Asian family as the less useful family here; however, pedagogically, this might itself create a challenging discussion in the classroom for the language learners to express this cultural issue freely in an academic friendly environment. In the second part of Chapter 3, the 'Reading' is on the comparison of two Australian cities, Melbourne and Sydney. Using adjectives like 'world-class', 'fabulous', 'excellent', 'wonderfully pleasant' and describing the two cities as 'paradise' or 'where ideas are discussed' and 'life is beautiful' are all cases of an idealistic view toward the cities of an English-speaking country. Yet again, the teachers might like to use this opportunity to give learners a chance to draw on the similarities 
or contrasts between their hometowns and these two Australian cities. Lesson A of Chapter 12 and its 'Grammar' section is another example in which a feeling of 'leave your country open up a new world to yourself' might indirectly be transferred to the reader. The case is a young Asian man who is saying goodbye to his family to go abroad and study English and he surely feels the confidence only 'after learning that language'. However, as a hot topic in Iran at least, this section would also be an opportunity for learners to embark on their experiences of leaving their home land.

There are more examples which dominate Target-Culture viewpoints all over the book. Besides, the bulk of pictures, texts and views of the course book are directed toward English-speakers in English-speaking countries. It is difficult to spot any content on the Source Culture and find Intercultural Interaction among various cultures. All in all, as Chao (2011) puts it, it seems that instead of seeking ways to pursue selfexploration, directing learners toward peer reflection and intercultural comparison as well as raising their awareness, EFL students are supposed to know the Western culture more than before after reading the content of this course book. Yet, needless to say that whatever covert syllabus a book contains, each and every section of it can alternatively be seen as prospects for both teachers and learners to have the maximum amount of interaction in EFL classes.

\section{CONCLUSION AND SUGGESTIONS}

In essence, this study highlights the high occurrence of partiality of the Target Culture in the course book analysed. The introduction of different viewpoints from Canadians, Australians, Americans and other English-speaking countries, the favored presentation of products of the West as well as a wide coverage of pictures and topics posed by the westerners are among the noticeable instances could be observed in Passages 1. In spite of all these examples, a pedagogic glance at these cultural contents can provoke heated cultural discussions that might be of help in raising intercultural awareness of EFL learners.

It would not be irrelevant claiming that the EFL learners' ideals and attitudes may explicitly or implicitly be influenced by the supremacy and ideology manifested in the ELT course books distributed in every corner of the world. The European and South American pictures, texts and topics receive the secondary emphasis as the authors have done something to include Intercultural Cultures and their pertinent content. However, little or almost none have allocated to the Middle East and its people and culture. The fact is, although this limitation can be educationally handled by using it as a learning opportunity, when EFL learners confront 'a minimum insufficient' dosage of the Source Culture, the feeling of disappointment and inferiority could be dominated to prompt them to stick to English-speaking cultures. Lastly, an adequate equal tangible amount of Intercultural Interaction could be pinpointed in the reading and oral practices of the course book. Yet, the pictures and listening and writing activities were not the reflection of an internationally printed book. A much culturally deeper piece of work could have been done if these activities had manifested intercultural realization, evaluation and alertness 
As a huge market of internationally printed course books, the Middle East in general and Iran in particular, deserve to be shown more than before to the world. It is an expectation since the authors have been to the Middle East a few times and they are aware of the variety of cultures worthy of inclusion in EFL/ESL course books. As Mikk (2000) puts it rightly, the course books learners read now affect their future thinking in different ways. Consequently, dos and don'ts of what, when and whose culture need to be incorporated in ELT course books are all fundamental concerns of experts in course book development industry. Most of the authors of these course books are worldfamous lecturers and researchers. They usually travel to every corner of the world and can see the eagerness of the Middle Easterners, as an example, to learn English.

It is therefore suggested that if there is no chance to invite non-native instructors or even such eager learners to the process of course book edition and design, the authors and international book publishers welcome all bits and pieces of the cross-culture communities of the world. After all, to borrow Canagarajah's (2003) words, practicing to challenge the existing Anglo-American cultural content, realizing imbalanced ideologies covert in the lines of a course book and becoming a critical thinker are extremely important skills that every ELT learner should possess. As Huang (2009) claims, it is time to shift our teaching and learning perspectives; a shift from a westernoriented framework to a national/local paradigm; the time to have balanced content on all cultures including the minorities; and the time to visualize all kinds of readers and their favorites to the extent possible. The provision of such a content let the EFL learners delve into their own cultural norms, observe the diversity of cultures worldwide and thoughtfully compare them with each other. After all, a one-sided view toward a specific culture deprives learners from their rights of experiencing intercultural communication. In cases where such ideals are missed, the existing course book content can be pedagogically used and focused on so that learning prospects dominate the course at hand.

Giving learners this opportunity is not merely the job of authors, but publishers and stakeholders. As EFL teachers, it is on us to avoid the cliché that whatever course books printed in the West is ready-to-use and with-no-flaw. Yet, provoking learners' questioning and critical abilities and choosing course books with enriched cultural content that foster their long-term intercultural competence would be a more academic and pedagogic decision.

\section{REFERENCES}

Ahmadi, Z. (2013). Evaluating Iranian and Non-Iranian English books in ELT from a cultural point of view. International Journal of Language and Linguistics, 1(4), 20-25.

Ajideh, P., \& Panahi, M. (2016). An analysis of culture-related content in English textbooks for Iranian students entitled 'Prospect' and 'Vision' Series. International Journal of Language and Linguistics, 3(6), 87-93.

Aliakbari, M. (2005). The place of culture in the Iranian ELT textbooks in high school level. Paper presented at the 9th Conference of Pan-Pacific Association of Applied Linguistics. Seoul, Korea.

Alpektin, C. (2002). Towards intercultural communicative competence in ELT. ELT Journal, 56(1), 57-64. 
Apple, M. W., \& Christian-Smith, L. K. (Eds.). (1991). The politics of the textbook. NY: Routledge.

Basttista, G. (1984). Language and culture: Strategies for teaching language in the classroom. Ann Arbor, Michigan: U.M.I.

Bennett, M. J. (1993). Towards ethnorelativism: A developmental model of intercultural sensitivity. In R. M. Paige (Ed.), Education for the intercultural experience (pp. 109135). Yarmouth, MN: Intercultural Press.

British Council, (2006). A review of the global market for English language course. Retrieved from: Https://www.britishcouncil.org/sites/default/files/a-review-of-the-global-marketfor-english-language-courses.pdf

Brooks, P. (2004). Cultural intelligence: A guide to working with people from other cultures. UK: Intercultural Press.

Byram, M. (1997). Teaching and assessing intercultural communicative competence. Clevedon: Multilingual Matters.

Byram, M., Nichols, A., \& Stevens, D. (2001). Developing intercultural competence in practice. Clevedon: Multilingual Matters.

Canagarajah, A. S. (2003). Resisting linguistic imperialism in English teaching Oxford: Oxford University Press.

Canale, M., \& Swain, M. (1980). Theoretical bases of communicative approaches to second language teaching and testing. Applied Linguistics, 1(1), 1-47.

Chang, S. C. (2004). Integrating cultural education into FL class for intercultural communication. Soochow Journal of Foreign Languages and Cultures, 19, 203-221.

Chao, T. C. (2009). Understanding university English learners' intercultural communication competence: Related studies and curriculum suggestions. Studies in International Cultures, 5(2), 49-86. (In Chinese)

Chao, T. C. (2010). A retrospective evaluation of a local college English textbook from an intercultural perspective. In Y. J. Chen, S. J. Huang, H. C. Liao and S. H. Lin (Eds.), Studies in English for Professional Communications and Applications (pp. 89-100). Taipei: Crane Publishing.

Chao, T. C. (2011). The hidden curriculum of cultural content in internationally published ELT textbooks: A closer look at New American Inside Out. The Journal of Asia TEFL, $8(2), 189-210$.

Choi, Y. H., \& Lee, H. W. (2008). Current trends and issues in English language education in Asia. The Journal of Asia TEFL, 5(2), 1-34.

Cohen, L., Manion, L., \& Morrison, K. (2000). Research methods in education (5 $5^{\text {th }}$ ed.). New York: RoutledgeFalmer.

Cortazzi, M., \& Jin, L. (1999). Cultural mirrors: Materials and methods in the EFL classroom. In E. Hinkel (Ed.) Culture in Second Language Teaching and Learning (pp. 149-176). Cambridge: Cambridge University Press.

Damen, L. (1987). Culture learning: The fifth dimension in the language classroom. Reading, MA: Addison-Wesley.

Fantini, A. E. (Ed.) (1997). New ways in teaching culture. Alexandria, VA: Teachers of English to Speakers of Other Languages, Inc.

Gill, S., \& Cánková, M. (2003). Intercultural activities. Oxford: Oxford University Press.

Giroux, H. A. (1988). Teachers as intellectuals: Toward a critical pedagogy of learning. Westport, Conn.: Bergin and Carvey.

Graddol, D. (2007). English next. UK: The British Council.

Hall, J. K. (2002). Teaching and researching language and culture. London: Longman/Pearson Education.

Huang, C. J. (1990). Putting democratic education into practice through hidden curriculum. Teachers' Friend Journal, 277, 16-18. (In Chinese).

Huang, C. J. (1993). The innovation of curriculum and instruction. Taipei: Shi-Da Book Publisher. (In Chinese) 
Huang, S. H., \& Lu, T.-J. (2006). A content analysis of the hidden curriculum in the sixth-grade English textbooks. Journal of Primary and Secondary Education, 17, 1-24. (In Chinese)

Huang, S. Y. (2009). Global English and EFL learners: Implications for critical pedagogy. The Journal of Asia TEFL, 6(3), 327-350.

Jackson, P. W. (1990). Preface. In Life in classrooms (p. xxi). New York: Teachers College Press.

Kramsch, C. (1991). Culture in language learning: A view from the United States. In K. Bot, R. B. Ginsbers, and C. Kramsch (Eds.), Foreign language research in cross-cultural perspective (pp. 89-125). Philadelphia: John Benjamins Publishing.

Kramsch, C. (1998). Language and culture. Oxford: Oxford University Press.

Lado, R. (1997). How to compare two cultures. In Heusinkveld (Ed.), Pathways to culture. Yarmouth, ME: Intercultural Press.

Lange, D. L., \& Paige, R. M. (2003). Interdisciplinary perspective on culture learning in the second language curriculum: Introduction. In D. L. Lange and R. M. Paige (Eds.), Culture as the core: Perspectives on culture in second language learning (pp. ix-xvii). US: Information Age Publishing.

Lázár, I. (2007). Theoretical background. In I. Lázár, M. Huber-Kriegler, D. Lussier, G. S. Matei and C. Peck (Eds.), Developing and accessing intercultural communicative competence: A guide for language teachers and teacher educators (pp. 7-10). Council of Europe Publishing.

Margolis, E. (2001). The hidden curriculum in higher education. New York and London: Routledge.

McKay, S. L. (2002). Teaching English as an international language. Oxford: Oxford University Press.

Mikk, J. (2000). Textbook: Research and writing. New York: P. Lang.

Moran, P. (2001). Teaching culture: Perspectives in practice. Boston, MA: Heinle \& Heinle.

Myles, B. S., \& Simpson, R. L. (2001). Understanding the hidden curriculum: An essential social skill for children and youth with asperser syndrome. Intervention in School and Clinic, 36, 279-286.

National Standards in Foreign Education Project (1999). Standards for foreign language learning in the 21st century. Yonkers, NY: National Standards in Foreign Language Education Project.

Neuman, W. L. (1997). Social research methods: Qualitative and quantitative approaches ( $3^{\text {rd }}$ ed.). MA: Allyn \& Bacon.

Pennycook, A. (1994). The cultural politics of English as an international language. New York: Longman.

Rashidi, N., \& Najafi, R. (2010). The representation of culture in Iran Language Institute Advanced level textbooks. Journal of Language Teaching and Research, 1(5), 624-631.

Richards, J. C., \& Sandy, C. (2015). Passages 1: Student's book (3rd ed.). New York: Cambridge University Press.

Scollon, R., \& Scollon, S. (1995). Intercultural communication: A discourse approach. Oxford: Blackwell.

Seelye, H. N. (1993). Teaching culture: Strategies for intercultural communication. Lincolnwood, IL: National Textbook Company.

Tomalin, B., \& Stempleski, S. (1994). Cultural awareness. Oxford: Oxford University Press.

Zacharias, N. T. (2005). Teachers' beliefs about internationally-published materials: A survey of tertiary English teachers in Indonesia. RELC Journal, 36(1), 23-37. 
An Example of Coding Guide for Cultural Classifications Analysis (Adopted From Chao, 2011)

\begin{tabular}{lll}
\hline Book Chapter & Reading Comprehensions & Cultural Classifications \\
& Listening Tracks & \\
& Oral Activities \\
& Writing Practices \\
& Pictorials
\end{tabular}

\section{AUTHORS}

Yazdan Choubsaz is a Ph.D. candidate in Applied Linguistics at Shahid Chamran University of Ahvaz, where he teaches the B.A. students general English and ESP courses. His area of interest includes CALL, MALL, classroom discourse, and teacher education.

Mohsen Jannejad is an assistant professor in linguistics at Shahid Chamran University of Ahvaz, Iran. He teaches sociolinguistics, syntax, phonetics, phonology and contrastive analysis to B.A., M.A., and Ph.D. students.

Saleh Arizavi is currently a Ph.D. candidate in Applied Linguistics at Shahid Chamran University of Ahvaz. He runs speaking/listening courses for B.A. English students as well as ESP. His area of interest includes academic writing, genre analysis, critical discourse analysis, critical assessment, and teacher education. 